\title{
Impact of Stomatal Density and Morphology on Water-Use Efficiency in a Changing World
}

\author{
Ligia T. Bertolino ${ }^{1,2}$, Robert S. Caine ${ }^{2}$ and Julie E. Gray ${ }^{2 *}$ \\ ${ }^{1}$ Grantham Centre for Sustainable Futures, University of Sheffield, Sheffield, United Kingdom, ${ }^{2}$ Department of Molecular \\ Biology and Biotechnology, University of Sheffield, Sheffield, United Kingdom
}

Global warming and associated precipitation changes will negatively impact on many agricultural ecosystems. Major food production areas are expected to experience reduced water availability and increased frequency of drought over the coming decades. In affected areas, this is expected to reduce the production of important food crops including wheat, rice, and maize. The development of crop varieties able to sustain or improve yields with less water input is, therefore, a priority for crop research. Almost all water used for plant growth is lost to the atmosphere by transpiration through stomatal pores on the leaf epidermis. By altering stomatal pore apertures, plants are able to optimize their $\mathrm{CO}_{2}$ uptake for photosynthesis while minimizing water loss. Over longer periods, stomatal development may also be adjusted, with stomatal size and density being adapted to suit the prevailing conditions. Several approaches to improve drought tolerance and water-use efficiency through the modification of stomatal traits have been tested in the model plant Arabidopsis thaliana. However, there is surprisingly little known about the stomata of crop species. Here, we review the current understanding of how stomatal number and morphology are involved in regulating water-use efficiency. Moreover, we discuss the potential and limitations of manipulating stomatal development to increase drought tolerance and to reduce water loss in crops as the climate changes.

Keywords: water-use efficiency, stomatal conductance, stomatal density and size, drought response, crops

\section{INTRODUCTION}

Changes in climate are already negatively affecting the yields of staple crops in agricultural areas around the world (Lobell et al., 2011; IPCC, 2014). As the globe continues to warm, changes in the hydrological cycles are, in general, increasing aridity and the incidence of droughts (Dai, 2013; Sherwood and Fu, 2014). Agriculture will need to adapt quickly to ensure that water is used more efficiently, while maintaining food security in a world where human population is rapidly growing. Sustainable and climate-smart management of water, land, and biodiversity will be important for achieving these objectives (discussed in Howden et al., 2007; Campbell et al., 2014; Lipper et al., 2014; Iglesias and Garrote, 2015). Moreover, the development of crop varieties that have improved water-use efficiency (WUE) under predicted future climates will also be critical (Flexas, 2016; Varshney et al., 2018). WUE can be estimated at different scales; at an agronomic level, it is described as the ratio of water used in crop production versus 
biomass or yield (Condon et al., 2004; Medrano et al., 2015). From a plant physiology point of view, and as it will be primarily addressed here, WUE is the amount of $\mathrm{CO}_{2}$ fixed in photosynthesis (A) relative to the amount of water vapor lost to the atmosphere (Willmer and Fricker, 1996; Condon et al., 2004; Bacon, 2004). As stomata play a fundamental role in regulating plant water use and carbon gain, they present a key target for improving WUE. Here, we review how changes in stomatal developmental traits can affect plant WUE and also drought tolerance.

Stomata are microscopic structures consisting of a pair of specialized guard cells that surround a central pore. They are found on aerial surfaces of most plants, providing access to mesophyll cells (Zeiger et al., 1987; Hetherington and Woodward, 2003). By actively adjusting guard cell turgor pressure, plants can alter stomatal pore aperture, thereby moderating gas exchange rates between the leaf interior and the atmosphere (Zeiger et al., 1987; Kollist et al., 2014). Increases in guard cell turgor pressure lead to a greater stomatal pore aperture, which enhances the rates of $\mathrm{CO}_{2}$ uptake for $A$ and of water loss, via a process termed stomatal conductance $\left(g_{s}\right)$ (Condon et al., 2002; Hetherington and Woodward, 2003). On the other hand, reductions in guard cell turgor pressure lead to decreases in stomatal aperture and in $g_{s}$. The signals governing the fluxes of $\mathrm{CO}_{2}$ and water to and from the plant mesophyll are highly coordinated, allowing plants to finely balance the need for carbon with the need to moderate water loss (Wong et al., 1979; Haworth et al., 2016; Sorrentino et al., 2016). This internal crosstalk is influenced by many environmental factors, including changes in temperature, light intensity, atmospheric $\mathrm{CO}_{2}$ concentration, air humidity, and soil moisture content (Farquhar and Sharkey, 1982; Schroeder et al., 2001; Mott, 2009; Assmann and Jegla, 2016; Chaves et al., 2016). For example, when water becomes limited, signals such as reduced hydraulic conductivity and increased abscisic acid (ABA) arise, causing guard cell turgor pressure decreases, which result in reduced stomatal aperture and $g_{s}$ (Schroeder et al., 2001; Mustilli, 2002; Tombesi et al., 2015; Bartlett et al., 2016; McAdam et al., 2016). These changes lead to an improved water conservation, but often at the expense of $A$ (Flexas and Medrano, 2002). Conversely, when water is plentiful in the soil or air, guard cell turgor increases, leading to increases in stomatal pore aperture and in $g_{s}$, with $A$ also often increasing.

Over longer periods, external signals perceived by mature leaves can also lead to systemic responses that moderate stomatal development on the new leaf epidermis, resulting in changes in stomatal patterning (Casson and Gray, 2008; Casson et al., 2010; Pillitteri and Torii, 2012; Chater et al., 2014; Qi and Torii, 2018).

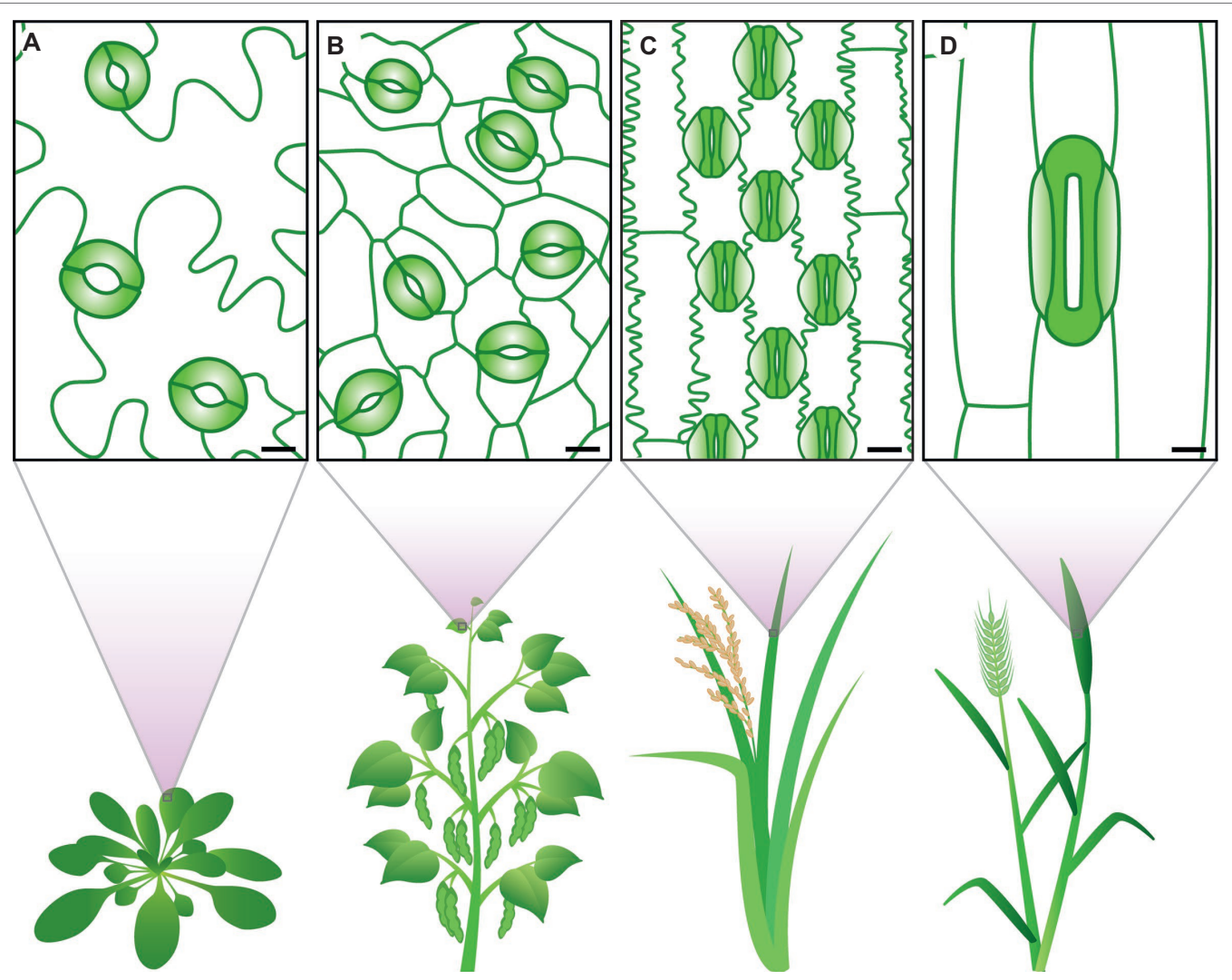

FIGURE 1 | Stomatal traits vary between species. The eudicots (A) Arabidopsis thaliana and (B) Phaseolus vulgaris display kidney-shaped guard cells (colored in green). The grasses (C) Oryza sativa and (D) Triticum aestivum show dumbbell-shaped guard cells (solid green) and specialized subsidiary cells (light green gradient). Clear differences in stomatal size and stomatal density can be observed. Scale bars $10 \mu \mathrm{M}$. 
Exposure of mature leaves to high $\mathrm{CO}_{2}$ or low light levels, for example, is known to cause reductions in stomatal density ( $S D$, number of stomata per unit of area) and in stomatal index (SI, ratio of stomata to epidermal cells plus stomata, multiplied by 100) of new developing leaves (Lake et al., 2001; Miyazawa et al., 2006). Conversely, low $\mathrm{CO}_{2}$ and high light generally have the opposite effect. The impact of water availability on stomatal development is less understood, with mixed responses and differences among species being reported (Clifford et al., 1995; $\mathrm{Xu}$ and Zhou, 2008; Doheny-Adams et al., 2012; Sun et al., 2014; Zhao et al., 2015). In Arabidopsis, plants grown under water restriction do not show altered $S D$; however, reductions in stomatal size (SS, guard cell area, based on guard cell pair length and width) were observed (Doheny-Adams et al., 2012). These plastic modulations of number and size of stomata allow plants to adjust their stomatal pore area in response to the surrounding environment, ultimately affecting their maximum and minimum gas exchange.

Stomata exhibit a diverse range of shapes, sizes, and numbers across different plant species (Figure 1). There are profound differences in how the stomata of different groups develop and are patterned on the epidermis (Sack, 1994; Caine et al., 2016; Raissig et al., 2016; Rudall et al., 2017). Morphological differences include $S D, S S$, guard cell shape, and presence or absence of subsidiary cells. All of these parameters have the potential to influence stomatal movement and, consequently, plant $A, g_{s,}$ and WUE. Over evolutionary time, various stomatal traits have altered, potentially aiding in adapting plant species to new environments (Taylor et al., 2012; Drake et al., 2013; Haworth et al., 2018). Eudicots, for example, typically have kidney-shaped stomata that are formed on the leaf epidermis without a pre-determined location (MacAlister et al., 2007; Pillitteri and Dong, 2013). While in monocots, stomata can either be kidney-shaped or, as with the grasses, be composed of dumbbell-shaped stomata with neighboring subsidiary cells, collectively termed a stomatal complex (Rudall et al., 2017). In grasses, stomatal development is constrained to the leaf base, with stomatal pores being formed in specified cell files adjacent to veins (Stebbins and Shah, 1960; Rudall et al., 2013; Hepworth et al., 2018).

Although stomatal behavior, patterning and morphology are important factors that contribute to WUE (Lawson and Blatt, 2014; Lawson and Vialet-Chabrand, 2019), relatively little is known about how targeted modifications of stomatal traits affect physiological responses in crop plants, especially in field experiments. Efforts to improve WUE have often led to decreases in yield (Flexas, 2016). By attempting to alter stomatal features to improve water conservation, reductions in $g_{s}$ may arise, potentially leading to detrimental effects on $A$, evaporative cooling, and plant fertility. However, recent findings suggest that under at least some greenhouse and controlled environment growth conditions, changing stomatal traits may improve WUE without such undesirable yield penalties (Yu et al., 2013; Hughes et al., 2017; Caine et al., 2019). While these studies are encouraging, they offer only a snapshot of how plants with modifications in stomatal features might perform. Here, we discuss our current understanding of how alterations in $S S, S D$, and stomatal morphology contribute to altered WUE and drought tolerance with particular emphasis on the latest advances in crop species.

\section{VARIATION IN SS AND SD INFLUENCES GASEOUS EXCHANGE AND WUE}

Dynamic adjustments to the opening degree of stomatal pores are responsible for regulating $g_{s}$ in the short term, allowing plants to quickly reduce water loss according to external cues (Farquhar and Sharkey, 1982). Over a longer term, anatomical adjustments, such as changes to $S S$ and $S D$, can modify the range of $g_{s}$ by altering the maximum stomatal conductance $\left(\mathrm{g}_{\text {smax }}\right)$ (Franks et al., 2009; Dow et al., 2014a). $G_{\text {smax }}$ refers to the maximal potential gas exchange in a state where all stomata are fully open. It is a theoretical estimate that is calculated using empirical stomatal anatomical measurements, including SD, stomatal pore depth (estimated as guard cell width), and maximum stomatal pore area (calculated based on pore length) (Franks and Beerling, 2009; Dow and Bergmann, 2014; Sack and Buckley, 2016). Despite operating $g_{s}$ normally being significantly lower than its maximum capacity (Fanourakis et al., 2015; McElwain et al., 2016), measured $g_{s}$ positively correlates with calculated $g_{\text {smax }}$ (Franks et al., 2009). Furthermore, it is suggested that adaptations in $g_{\text {smax }}$ allow plants to adjust their operating gas exchange rates while maintaining guard cells turgor pressure in an optimum state. This is believed to provide better stomatal sensitivity and rapid adjustment of aperture response (Franks et al., 2012; Dow and Bergmann, 2014). Therefore, although $S S$ and $S D$ are not the only variables determining leaf gas exchange, changes to these stomatal traits do permit plants to adjust both $A$ and water use (Franks et al., 2009; Franks and Beerling, 2009; de Boer et al., 2011; Dow et al., 2014a).

Variation in size and density of stomata may arise due to genetic factors and/or growth under different environmental conditions. A negative correlation has frequently been suggested between these two stomatal traits. This inverse relationship has been observed in plastic developmental responses to changes in environment and also during long-term evolutionary adaptation (Dilcher et al., 2000; Ohsumi et al., 2007; Franks et al., 2009, 2012; Franks and Beerling, 2009; Doheny-Adams et al., 2012; Taylor et al., 2012; Sun et al., 2014; Fanourakis et al., 2015; de Boer et al., 2016; Dittberner et al., 2018). Analysis of herbarium and fossilized plant remains suggest that SS and $S D$ have changed in response to atmospheric $\mathrm{CO}_{2}$ concentration over evolutionary time, probably to enable adjustments to $g_{\text {smax }}$ and $\mathrm{CO}_{2}$ diffusion into the leaf (Woodward, 1987; Dilcher et al., 2000; Franks and Beerling, 2009). In samples from periods when $\mathrm{CO}_{2}$ concentrations were low, a reduction in $S S$ and an increase in $S D$ have been observed. On the other hand, when atmospheric $\mathrm{CO}_{2}$ levels have been high, $S S$ has increased and $S D$ decreased. Such adaptive responses to $\mathrm{CO}_{2}$ are also found in many extant lineages; however, this is not always the case in all species surveyed (Casson and Gray, 2008; Haworth et al., 2013; Field et al., 2015).

Although various combinations of $S S$ and $S D$ can result in similar alteration to $g_{\text {smax }}$, there are limitations as to how much 
of the epidermis can be patterned by stomata. First, other functionally important leaf structures such as veins and trichomes are also absolutely required. Second, stomata need to be spaced by at least one epidermal cell to function efficiently (Franks and Farquhar, 2007; Dow et al., 2014b). Therefore, changes to $S S$ and $S D$ are limited to a finite portion of the epidermis (Franks et al., 2009; Franks and Beerling, 2009; de Boer et al., 2016). In general, plants optimize $g_{\text {smax }}$ through investing in increases in $S D$ coupled with reductions in SS (Franks and Beerling, 2009; de Boer et al., 2012). According to Franks and Beerling (2009) and Franks and Farquhar (2007), changes toward increased $S D$ in combination with reduced $S S$ could maintain or improve total pore area (due to increased $S D$ ) but can also provide a shorter diffusion path (due to the smaller pore depth), potentially resulting in improved gas exchange.

While small $S S$ coupled with high $S D$ often leads to a higher $g_{s \operatorname{smax}}$ it is also possible for $g_{\text {smax }}$ to be reduced by a smaller SS alone. Decreases in $g_{\text {smax }}$ due to a smaller SS have been associated with higher water conservation, as reported for plants exposed to drought (Doheny-Adams et al., 2012) and ABA treatment (Franks and Farquhar, 2001). Smaller stomata are also associated with improved WUE in Arabidopsis thaliana (Dittberner et al., 2018); and rice varieties with smaller SS have the ability to strongly decrease $g_{s}$ under drought (Ouyang et al., 2017). Growth under low soil moisture conditions has been shown to cause a decrease in SS in several species (Xu and Zhou, 2008; DohenyAdams et al., 2012; Sun et al., 2014; Zhao et al., 2015), but the effect on $S D$ is less consistent (Clifford et al., 1995; Xu and Zhou, 2008; Doheny-Adams et al., 2012; Sun et al., 2014; Zhao et al., 2015). Stomatal size and density responses to vapor pressure deficit (VPD) are also variable. Under high VPD conditions, the woody angiosperm, Toona ciliata, displays smaller SS and higher SD (Carins Murphy et al., 2014), while tomato and sweet pepper show decreases in both stomatal traits (Bakker, 1991), and in poplar, changes in $S D$ are dependent on $\mathrm{CO}_{2}$ concentration. (Miyazawa et al., 2006). Thus, changes in SS and $S D$ in response to soil moisture or VPD appear to be specific to species and environmental variables (Bakker, 1991; Miyazawa et al., 2006; Xu and Zhou, 2008; Sun et al., 2014). Nutrient availability can also affect plant development. However, as described for soil moisture and VPD responses, adjustments in stomatal development in response to nutrient availability appear to be variable with no consistent response emerging (Gao et al., 2006; Sekiya and Yano, 2008; Yan et al., 2012; Sun et al., 2014; Hepworth et al., 2016).

\section{ARE SMALL STOMATA FASTER?}

Small stomatal size can provide a reduction in total leaf pore area and might also facilitate faster aperture response (Franks and Beerling, 2009; Drake et al., 2013; Lawson and Blatt, 2014). The higher cell surface area to volume ratio of smaller cells is believed to permit faster ion fluxes, leading to faster guard cell turgor changes and a more rapid $g_{s}$ response (Lawson and Vialet-Chabrand, 2019). This faster stomatal behavior in plants with smaller SS has been observed in response to changes in light intensity across species of Banksia, rainforest trees, and in cereal species with dumbbell-shaped guard cells (Drake et al., 2013; McAusland et al., 2016; Kardiman and Raebild, 2017). However, although rapid stomatal movements might help to maximize WUE under fluctuating light environments, this is unlikely to have much impact on water loss over long periods of water stress under field conditions.

SS is clearly not the only anatomical trait influencing stomatal behavior. The shape of guard cells and the presence of subsidiary cells are also suggested to impact on stomatal responses (as discussed in "Stomatal morphology and improved WUE" below). In addition, the distribution of stomata between leaf abaxial and adaxial surfaces may also affect plant responses to environmental stresses. For example, stomata on the abaxial surfaces of wheat leaves show a stronger decrease in $g_{s}$ than adaxial stomata when they are exposed to water stress $(\mathrm{Lu}$, 1989), and abaxial and adaxial stomata of cotton show differing responses to light quality (Lu et al., 1993). Moreover, as shown by Elliott-Kingston et al. (2016), Haworth et al. (2018), and McAusland et al. (2016), simple differences in SS do not always correlate with stomatal speed, especially when comparing distant taxa. Comparisons of cultivars or mutants of the same species with altered $S S$, but similar $S D$, would improve our understanding of the effect of guard cell size on speed of stomatal movement and explore if there is potential for SS as trait for improving WUE. Although a correlation between SS and genome size has been documented (Beaulieu et al., 2008; Jordan et al., 2015; Monda et al., 2016), the genetic and molecular mechanisms regulating SS remain unstudied, which currently limits our understanding of this trait.

\section{TARGETED CHANGES IN SD LEADING TO ALTERATIONS IN WUE}

Reductions in $S D$ also have the potential to constrain $g_{s}$ and transpiration $(E)$, representing a shift towards a more conservative use of water. If not limiting $A$ or evaporative cooling, this reduction in water loss should represent an advantage under low water availability scenarios. In comparison to SS, significant advances have been made in understanding the molecular signals regulating stomatal density and patterning, which allow the study of the physiological effects of altering $S D$. Stomatal development in Arabidopsis thaliana is controlled by a complex genetic network, of which the basic helixloop-helix (bHLH) transcription factors SPCH, MUTE, and FAMA together with either ICE1/SCREAM (SCRM) or SCRM2 control the sequential cell fate transitions. Additionally, an intercellular signaling pathway that includes peptide ligands, leucine-rich repeat receptor kinases (LRR-RKs) and a MAPK cascade, regulates the activity of the bHLHs (reviewed in Bergmann and Sack, 2007; Vatén and Bergmann, 2012; Zoulias et al., 2018). This signaling network includes the secretory peptides EPIDERMAL PATTERNING FACTOR1 (EPF1), EPF2, and EPF-like 9. EPF1 and EPF2 both negatively regulate stomatal density, with EPF1 also preventing stomatal clustering (Hara et al., 2007; Hunt and Gray, 2009), while EPFL9 
functions antagonistically to promote stomatal development (Hunt et al., 2010; Sugano et al., 2010; Lee et al., 2015).

In Arabidopsis, the overexpression of AtEPF2 results in plants with particularly low $S D$. Despite a coupled increase in $S S$, these plants have significantly lower $g_{s}$ and $g_{\text {smax }}$, with minor reductions in carbon assimilation, leading to an increase in intrinsic WUE (iWUE, estimated by $A / g_{s}$ to water vapor) (Doheny-Adams et al., 2012; Franks et al., 2015). The large reduction in $S D$ resulted in plants with improved tolerance to drought, without detrimental effects to uptake of nitrogen or phosphate (Hepworth et al., 2015, 2016). Improved plant drought responses were also achieved by Wang et al. (2016) in poplar plants overexpressing PdEPF1. Transgenic poplar lines showed a $28 \%$ reduction in $S D$, which led to a $30 \%$ decrease in $E$, despite an increase in SS. WUE and drought tolerance were improved in poplar plants with lower $S D$, which also showed relatively lower decreases in levels of $A$ and biomass under water restricted conditions (Wang et al., 2016). The manipulation of another regulator of stomatal development, the subtilisin-like protease STOMATAL DENSITY AND DISTRIBUTION1 (SDD1), also leads to a significant alteration to $S D$ in Arabidopsis, with overexpression of this gene reducing SD by $40 \%$ (Von Groll et al., 2002). This reduction was translated into a lower $g_{s}$ under high light intensities; however, $A$ was compromised under some light conditions (Büssis et al., 2006). A more encouraging result was achieved by Yoo et al. (2010) by manipulating a transcriptional repressor of SDD1, GT-2 LIKE 1 (GTL1). GTL1 loss-of-function Arabidopsis mutants had higher SDD1 expression resulting in lower $S D$ and $g_{s}$, without detrimental effects to the photosynthetic rates over a range of light levels. The lower water loss observed in the gtl1 mutants significantly improved WUE, when water loss versus shoot dry weight was assessed. Taken together, these data indicate that it is possible to improve WUE by altering $g_{\text {smax }}$ and $g_{s}$ using genetic engineering tools. It is not fully understood, however, how severe reductions in $g_{\text {smax }}$ may limit short-term stomatal responses or whether adjustments to stomatal development in response to changes in environmental conditions would be affected in these genetically modified plants.

Although stomatal development in grasses differs from that of eudicots in various aspects, recent findings demonstrate that several components of the stomatal signaling pathway, including bHLH transcription factors (Liu et al., 2009; Raissig et al., 2016, 2017) and peptide signals controlling stomatal density, mediate similar events (Hughes et al., 2017; Yin et al., 2017; Caine et al., 2019). This has allowed researchers to begin to test the implications of targeted manipulations in stomatal density in grasses, a family of plants that comprises many important food crops. Research on barley and rice (further discussed below) shows that the overexpression of EPF1 can result in improved WUE without yield penalty, despite in some cases small reductions in photosynthetic rate under well-watered conditions (Hughes et al., 2017; Caine et al., 2019). Interestingly, in both crops, an increase in guard cell size was not observed in plants with reduced $S D$, contrasting with that described for poplar and Arabidopsis above. These observations suggest that the response of $S S$ to altered $S D$ may be differentially regulated between monocots and eudicots.

\section{STOMATAL MORPHOLOGY AND IMPROVED WUE}

The shape of guard cells and the presence or absence of subsidiary cells have implications for the mechanics and responsiveness of stomatal movement (Franks and Farquhar, 2007). Diversity in stomatal morphology is commonly observed across species and can be linked to adaptability to certain environments (Chen et al., 2017; Müller et al., 2017). In the grass family, for example, stomatal morphology has often been hypothesized to have contributed to successful diversification, particularly in habitats with fluctuating water availability (Hetherington and Woodward, 2003; Cai et al., 2017; Chen et al., 2017). In contrast to the two kidney-shaped guard cells observed in many species, grass species develop stomatal complexes formed by a pair of dumbbellshaped guard cells, which are flanked by two paracytic subsidiary cells (Stebbins and Shah, 1960; Sack, 1994; Rudall et al., 2017; Hepworth et al., 2018; McKown and Bergmann, 2018). Several studies comparing stomatal opening and closing responses, between grasses and species with kidney-shaped stomata, suggest that grasses exhibit faster and more efficient stomatal regulation (Grantz and Zeiger, 1986; Vico et al., 2011; Merilo et al., 2014; McAusland et al., 2016; Haworth et al., 2018). The linear dumbbellshaped guard cells require only small changes in volume to bring about stomatal opening and, consequently, to achieve a higher diffusible pore area (Hetherington and Woodward, 2003). The large and rapid responses of grass stomata are also related to the physical interaction between dumbbell-shaped guard cells and flanking subsidiary cells. Subsidiary cells are not only able to limit but also to accommodate guard cell movement, providing a mechanical advantage (Franks and Farquhar, 2007). They function by promptly supplying ions to guard cells, facilitating a reciprocal change in turgor pressure (Raschke and Fellows, 1971; Franks and Farquhar, 2007; Schäfer et al., 2018). This efficient osmotic flux aids rapid stomatal movement and therefore is believed to confer adaptive advantages to grasses.

Slow stomatal responses are proposed to lead to less efficient uptake of $\mathrm{CO}_{2}$ during stomatal opening and unnecessary water loss during stomatal closure (McAusland et al., 2016; Lawson and Vialet-Chabrand, 2019). Under particular environmental conditions (e.g., fluctuations in irradiance), plants with stomata which are highly responsive might achieve higher WUE. Recently, the absence of subsidiary cells was investigated in Brachypodium distachyon plants with a mutation in BdMUTE, an ortholog of an Arabidopsis bHLH gene. Mutant plants lacking subsidiary cells failed to open guard cells as widely as control plants and also showed slower stomatal responses to changes in light intensity, further suggesting that subsidiary cells are integral for efficient stomatal functioning in grasses (Raissig et al., 2017). The receptor-like proteins PANGLOSS (PAN) 1 and PAN2 are also integral for the formation of subsidiary cells, primarily by enabling subsidiary mother cells to polarize in the correct orientation to guard mother cells during stomatal 
development (Cartwright et al., 2009; Zhang et al., 2012; Sutimantanapi et al., 2014). Defective pan1 and pan2 mutants and pan1/pan 2 double mutants have misshapen subsidiary cells, which could impact on stomatal responsiveness; however, it is not known whether gas exchange is affected in these mutant plants. Despite the relatively recent discoveries of MUTE and PAN proteins in grasses, there are still many unanswered questions in relation to subsidiary and guard cell interactions, especially in non-grass species, which show a diversity of stomatal complex morphologies, with different numbers and positions of subsidiary cells (Rudall et al., 2017). Further study of how the diversity of stomatal complex morphologies affects plant physiology could improve our understanding of how these features might contribute to improved WUE.

\section{GENETIC MANIPULATION OF STOMATAL DEVELOPMENT IN CROPS, THE IMPLICATIONS FOR WUE, AND DROUGHT RESPONSES}

An increasing number of genetic resources are enabling researchers to test whether targeted alterations in stomatal development can improve WUE and drought tolerance in crop species (Winter et al., 2007; Goodstein et al., 2012; Yin et al., 2017). Although results are yet to be demonstrated in the field, in overexpressing orthologs of Arabidopsis $S D D 1$ in maize and tomato, respectively, Liu et al. (2015) and Morales-Navarro et al. (2018) have been able to reduce leaf $S D$, leading to reduced water consumption and improved drought tolerance in both crops, as well as improved WUE in maize. Similar results were achieved in barley by overexpressing HvEPF1 (Hughes et al., 2017). With approximately $50 \%$ reduction in $S D$ and shorter guard cells, under drought conditions, transgenic barley lines were able to retain higher levels of soil water content. These plants were able to avoid water stress for longer periods, showing drops in photosystem II activity 4-5 days later than the control plants. Carbon isotope analysis suggested that plants with reduced $S D$ had improved WUE under the water stress treatment, and despite small reductions in $A$, no detrimental effects on plant growth or yield were observed (Hughes et al., 2017). Similarly, overexpression of rice OSEPF1 resulted in rice plants with improved WUE (Caine et al., 2019). Two genetically modified lines, one with moderate $(\sim 58 \%)$ and the other with severe $(\sim 88 \%)$ reductions in $S D$, had improved water conservation during the vegetative stage, using $42 \%$ and $38 \%$ less water, respectively, than the control.

An opposite effect on stomatal development was created by overexpressing the maize gene SHORTROOT 1 (ZmSHR1) in rice, leading to higher $S D$ and in some cases reduced $S S$ (Schuler et al., 2018). Despite the changes in stomatal properties, neither $A$ nor $g_{s}$ was significantly different from controls suggesting that increased $S D$ neither positively or negatively impacted on gaseous exchange. In this particular study, WUE was not reported, but based on $A$ and $g_{s}$ values, alterations seem unlikely. Given the predicted temperature increases for the coming century, however, crop plants with more stomata and potentially increased gas exchange capacity may be important in mitigating the effects of heat stress through increased transpiration-mediated cooling.

While most of the crop studies discussed above have characterized drought and photosynthetic performance, to better understand how crops with altered $S D$, $S S$, or function might perform under future climate scenarios, it is important to consider the combinatory effects of multiple abiotic factors. Of particular importance are the predicted reductions in water availability, increasing atmospheric $\mathrm{CO}_{2}$, concentration, and increasing temperature. While reduced water availability and elevated $\mathrm{CO}_{2}$ often result in stomatal closure leading to reduced $g_{s}$, increased temperature might have the opposite effect, forcing stomata to open to mitigate the effects of overheating (Zhou et al., 2007; Chaves et al., 2016; Caine et al., 2019). This essentially means that in future climates, if plants are going to conserve water, they may be less able to prevent overheating, possibly leading to photoinhibition, leaf damage, and reduction in yields.

This trade-off between WUE and evaporative cooling was recently investigated in the OsEPF1 overexpressing (OsEPF1oe) rice. Under well-watered conditions at high temperature $\left(40^{\circ} \mathrm{C}\right)$, plants with substantially reduced $S D$ (and $S S$ ) exhibited increased $g_{s}$, reaching similar rates as control plants. The increase in gas exchange rates were seemingly achieved through regulation of

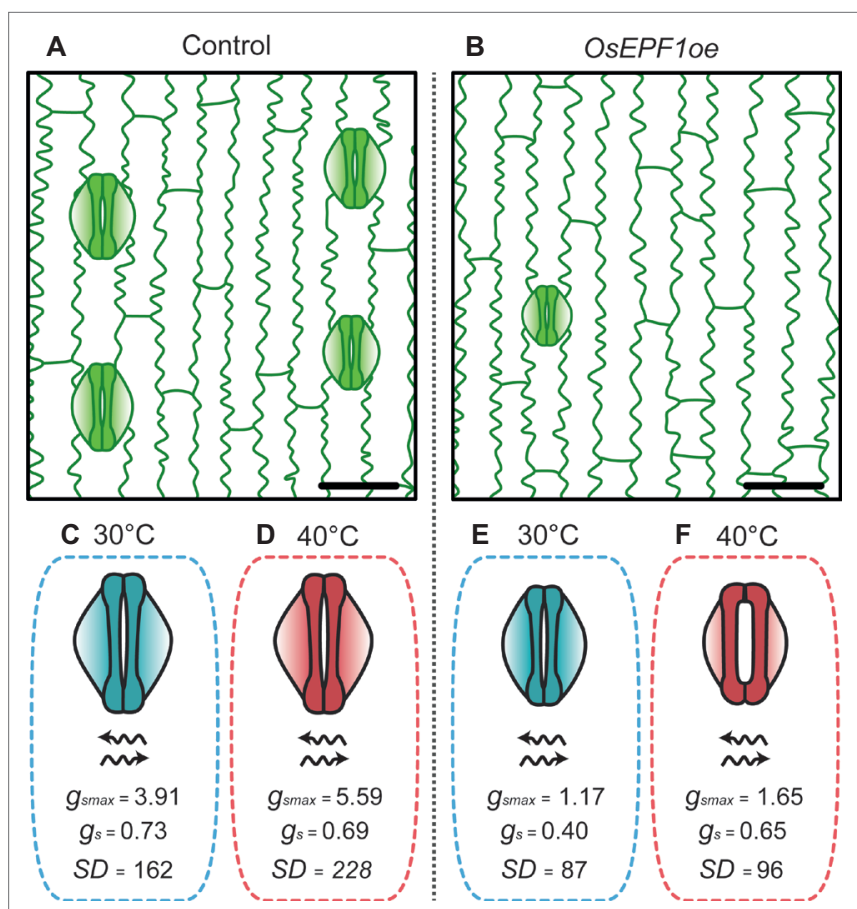

FIGURE 2 | OSEPF10e rice plants with reduced stomatal density and size are able to maintain high rates of gas exchange under heat stress conditions by opening their stomatal pores (adapted from Caine et al., 2019).

Epidermis of (A) non-transgenic control and (B) OsEPF1oe plants grown at $30^{\circ} \mathrm{C}$, bars $=25 \mu \mathrm{M}$. Stomata of control plants grown at (C) $30^{\circ} \mathrm{C}$ and (D) $40^{\circ} \mathrm{C}$. Control plants show increases in stomatal density and in maximum leaf stomatal conductance average values under high temperature conditions. OsEPF10e plants grown at (E) $30^{\circ} \mathrm{C}$ and $\mathbf{( F )} 40^{\circ} \mathrm{C}$. Transgenic line shows an increase in stomatal aperture at $40^{\circ} \mathrm{C}$, reaching similar $g_{s}$ levels as control plants, despite lower maximum stomatal conductance. Units: $g_{\text {smax }}$ and $g_{\mathrm{s}}=\mathrm{mol} \mathrm{m} \mathrm{m}^{-2} \mathrm{~s}^{-1}, \mathrm{SD}=\mathrm{mm}^{-2}$ 
stomatal apertures (Figure 2), with the trade-off being a loss of superior WUE relative to control plants (Caine et al., 2019). However, at $40^{\circ} \mathrm{C}$, OsEPF1oe plants with severe $S D$ reductions showed enhanced survival rates under drought stress, perhaps because of their improved soil water conservation under these conditions. Although these responses suggest that having low $S D$ with reduced SS could be beneficial at very high temperature, at present the operational dynamics of stomata when temperature exceeds $40^{\circ} \mathrm{C}$ are not well understood. Modeling of $g_{\text {smax }}$ suggested that despite the much reduced $S D$, OsEPF1oe plants still use only up to $40 \%$ of their theoretical maximum gas exchange capacity at $40^{\circ} \mathrm{C}$, but the actual level of $g_{s}$ (and $A$ and WUE) at more extreme temperatures remains untested (Caine et al., 2019). These results raise a number of questions regarding the physiological behavior of these reduced SD plants. Firstly, will plants with fewer, smaller stomata be capable of continuing to increase $g_{s}$ to maintain water flow and $A$ at extreme temperatures, and will this be at the expense of WUE? If so, will plants with the lowest $S D$ be less water-use efficient than plants with higher $S D$ at very high temperatures in order to maintain cooling? The answers to such questions are critical to understand if targeted $S D$ reductions are to be an effective tool to improve rice production in areas where drought and high temperatures are predicted to become more prevalent.

\section{OTHER POTENTIAL STOMATAL- RELATED TARGETS TO IMPROVE WUE}

The central position of stomata in the gas exchange process makes them an obvious target for improving WUE; nonetheless, the manipulation of other processes with potential for improving plant carbon and water relations has also been investigated (Lefebvre et al., 2005; Taylor et al., 2011; Ort et al., 2015; Kromdijk et al., 2016; Głowacka et al., 2018). Alterations in mesophyll conductance $\left(g_{m}\right)$, for example, can have a great impact in $A$, and its coregulation with $g_{s}$ is essential for plant WUE. Indeed, it has been suggested that increases in $g_{m}$ coupled with decreases in $g_{s}$ could improve WUE, without the potential detrimental impacts in $A$ and yield (Flexas et al., 2013).

Moreover, stomata are not the only structures on the epidermis to prevent water loss - trichomes, the cuticle, and cuticular waxes are also important (Guo et al., 2016; Ichie et al., 2016; Bi et al., 2017; Zeisler-Diehl et al., 2018). While research into crop plant stomata is of long-standing (Teare et al., 1971; Gay and Hurd, 1975; Liao et al., 2005; Ohsumi et al., 2007), new approaches are looking at drought-tolerant relatives of crops or desert-growing species for novel ways to increase WUE. For example, by crossing the wild drought tolerant tomato relative, Solanum pennellii (which has abundant trichomes), with the cultivated species Solanum lycopersicum, Galdon-Armero et al. (2018) showed that the coordinated development of trichomes and stomata may be a key tool for enhancing WUE in crops. It was found that the plants with the best WUE were those with the highest ratio of trichomes to stomata. One possible explanation for this is that plants with fewer stomata and abundant trichomes have a more significant boundary layer, thus creating a greater resistance to diffusion of water from the leaf (GaldonArmero et al., 2018). Another example of increased resistance to diffusion of water due to adaptations to the epidermis has also recently been reported in the desert crop, date palm (Phoenix dactylifera) (Müller et al., 2017). In this study, wax chimneys were detected on the cuticle that encircled stomata, which like trichomes, prevented excessive water loss, thereby potentially improving WUE. Further investigations exploring how stomata and other epidermal structures jointly contribute to regulate WUE may be a critical piece in the jigsaw of preserving water and negating drought. Indeed, the recent discovery of the Fused Outer Cuticular Ledge1 stomata gene in Arabidopsis may help facilitate such studies (Hunt et al., 2017).

\section{CONCLUSION}

The knowledge relating to the genetics underpinning stomatal development and physiology in both Arabidopsis and crop species has advanced substantially, with noticeable advancements made in improving WUE. However, there are still many questions to answer, of particular importance is how $S S$ is regulated at the genetic level and why do $S S-S D$ responses vary so much between species. In addition to this, understanding how stomatal complex architecture is modified and how ion fluxes are directed between guard and subsidiary cells at the genetic level is the key area where further advances in knowledge are required. In crops, recent studies are showing that engineering plants to reduce stomatal number may be an effective tool to improve plant WUE and drought tolerance without yield reductions. Of course, as modified plants have typically been evaluated in laboratory conditions, it is still necessary to answer how such plants might perform in the real world. In a field context, many other environmental variables and stressors will impact on performance. Additional studies are necessary to understand how plants with altered stomatal development will respond to multiple stresses in different developmental phases. Moreover, combining changes in stomatal traits with other alterations associated with improved water relations, such as modifications to the leaf epidermis, photosynthesis, $g_{m}$, and root growth, among others, could further benefit plant WUE and drought tolerance under future predicted climate scenarios.

\section{AUTHOR CONTRIBUTIONS}

LB and RC wrote the paper. LB designed the figures. JG provided advice and comments. All authors read, commented on, and approved this version of the manuscript.

\section{FUNDING}

The authors are supported by the Grantham Centre for Sustainable Futures-Funded a PhD scholarship (LB) and the BBSRC Newton Fund-grant BB/N013646/1-Funded group's research (RC and JG). University of Sheffield library—to fund journal fees. 


\section{REFERENCES}

Assmann, S. M., and Jegla, T. (2016). Guard cell sensory systems: recent insights on stomatal responses to light, abscisic acid, and $\mathrm{CO}_{2}$. Curr. Opin. Plant Biol. 33, 157-167. doi: 10.1016/J.PBI.2016.07.003

Bacon, M. (2004). Water use efficiency in plant biology. Oxford, UK: Blackwell.

Bakker, J. C. (1991). Effects of humidity on stomatal density and its relation to leaf conductance. Sci. Hortic. 48, 205-212. doi: 10.1016/0304-4238(91)90128-L

Bartlett, M. K., Klein, T., Jansen, S., Choat, B., and Sack, L. (2016). The correlations and sequence of plant stomatal, hydraulic, and wilting responses to drought. Proc. Natl. Acad. Sci. U. S. A. 113, 13098-13103. doi: 10.1073/ pnas. 1604088113

Beaulieu, J. M., Leitch, I. J., Patel, S., Pendharkar, A., and Knight, C. A. (2008). Genome size is a strong predictor of cell size and stomatal density in angiosperms. New Phytol. 179, 975-986. doi: 10.1111/j.1469-8137.2008.02528.x

Bergmann, D. C., and Sack, F. D. (2007). Stomatal development. Annu. Rev. Plant Biol. 58, 163-181. doi: 10.1146/annurev.arplant.58.032806.104023

Bi, H., Kovalchuk, N., Langridge, P., Tricker, P. J., Lopato, S., and Borisjuk, N. (2017). The impact of drought on wheat leaf cuticle properties. BMC Plant Biol. 17:85. doi: 10.1186/s12870-017-1033-3

Büssis, D., Von Groll, B. U., Fisahn, J., and Altmann, T. (2006). Stomatal aperture can compensate altered stomatal density in Arabidopsis thaliana at growth light conditions. Funct. Plant Biol. 33, 1037-1043. doi: 10.1071/FP06078

Cai, S., Papanatsiou, M., Blatt, M. R., and Chen, Z. -H. (2017). Speedy grass stomata: emerging molecular and evolutionary features. Mol. Plant 10, 912-914. doi: 10.1016/j.molp.2017.06.002

Caine, R., Chater, C. C., Kamisugi, Y., Cuming, A. C., Beerling, D. J., Gray, J. E., et al. (2016). An ancestral stomatal patterning module revealed in the nonvascular land plant Physcomitrella patens. Development 143, 3306-3314. doi: 10.1242/dev.135038

Caine, R. S., Yin, X., Sloan, J., Harrison, E. L., Mohammed, U., Fulton, T., et al. (2019). Rice with reduced stomatal density conserves water and has improved drought tolerance under future climate conditions. New Phytol. 221, 371-384. doi: $10.1111 / \mathrm{nph} .15344$

Campbell, B. M., Thornton, P., Zougmoré, R., van Asten, P., and Lipper, L. (2014). Sustainable intensification: what is its role in climate smart agriculture? Curr. Opin. Environ. Sustain. 8, 39-43. doi: 10.1016/J.COSUST.2014.07.002

Carins Murphy, M. R., Jordan, G. J., and Brodribb, T. J. (2014). Acclimation to humidity modifies the link between leaf size and the density of veins and stomata. Plant Cell Environ. 37, 124-131. doi: 10.1111/pce.12136

Cartwright, H. N., Humphries, J. A., and Smith, L. G. (2009). PAN1: a receptorlike protein that promotes polarization of an asymmetric cell division in maize. Science 323, 649-651. doi: 10.1126/science.1161686

Casson, S. A., Hetherington, A. M., Bergmann, D. C., and Fleming, A. J. (2010). Environmental regulation of stomatal development This review comes from a themed issue on Growth and Development Edited. Curr. Opin. Plant Biol. 13, 90-95. doi: 10.1016/j.pbi.2009.08.005

Casson, S., and Gray, J. E. (2008). Influence of environmental factors on stomatal development. New Phytol. 178, 9-23. doi: 10.1111/j.1469-8137.2007.02351.x

Chater, C. C. C., Oliver, J., Casson, S., and Gray, J. E. (2014). Putting the brakes on: abscisic acid as a central environmental regulator of stomatal development. New Phytol. 202, 376-391. doi: 10.1111/nph.12713

Chaves, M. M., Costa, J. M., Zarrouk, O., Pinheiro, C., Lopes, C. M., and Pereira, J. S. (2016). Controlling stomatal aperture in semi-arid regions-The dilemma of saving water or being cool? Plant Sci. 251, 54-64. doi: 10.1016/J. PLANTSCI.2016.06.015

Chen, Z. -H., Chen, G., Dai, F., Wang, Y., Hills, A., Ruan, Y. -L., et al. (2017). Molecular evolution of grass stomata. Trends Plant Sci. 22, 124-139. doi: 10.1016/j.tplants.2016.09.005

Clifford, S. C., Black, C. R., Roberts, J. A., Stronach, I. M., Singleton-Jones, P. R., Mohamed, A. D., et al. (1995). The effect of elevated atmospheric $\mathrm{CO}_{2}$ and drought onstomatal frequency in groundnut (Arachis hypogaea (L.)). J. Exp. Bot. 46, 847-852. doi: 10.1017/CBO9781107415324.004

Condon, A. G., Richards, R. A., Rebetzke, G. J., and Farquhar, G. D. (2002). Improving intrinsic water-use efficiency and crop yield. Crop Sci. 42, 122-131. doi: $10.2135 /$ cropsci2002.1220

Condon, A. G., Richards, R. A., Rebetzke, G. J., and Farquhar, G. D. (2004). Breeding for high water-use efficiency. J. Exp. Bot. 2447-2460. doi: 10.1093/ jxb/erh277
Dai, A. (2013). Increasing drought under global warming in observations and models. Nat. Clim. Chang. 3, 52-58. doi: 10.1038/nclimate1633

de Boer, H. J., Eppinga, M. B., Wassen, M. J., and Dekker, S. C. (2012). A critical transition in leaf evolution facilitated the Cretaceous angiosperm revolution. Nat. Commun. 3, 1221. doi: 10.1038/ncomms 2217

de Boer, H. J., Lammertsma, E. I., Wagner-Cremer, F., Dilcher, D. L., Wassen, M. J., and Dekker, S. C. (2011). Climate forcing due to optimization of maximal leaf conductance in subtropical vegetation under rising $\mathrm{CO}_{2}$. Proc. Natl. Acad. Sci. U. S. A. 108, 4041-4046. doi: 10.1073/pnas.1100555108

de Boer, H. J., Price, C. A., Wagner-Cremer, F., Dekker, S. C., Franks, P. J., and Veneklaas, E. J. (2016). Optimal allocation of leaf epidermal area for gas exchange. New Phytol. 210, 1219-1228. doi: 10.1111/nph.13929

Dilcher, D., de Boer, H. J., Dekker, S. C., Dilcher, D. L., Lotter, A. F., and Wagner-Cremer, F. (2000). Toward a new synthesis: major evolutionary trends in the angiosperm fossil record. Proc. Natl. Acad. Sci. 97, 7030-7036. doi: 10.1073 /pnas.97.13.7030

Dittberner, H., Korte, A., Mettler-Altmann, T., Weber, A. P. M., Monroe, G., and de Meaux, J. (2018). Natural variation in stomata size contributes to the local adaptation of water-use efficiency in Arabidopsis thaliana. Mol. Ecol. doi: $10.1111 / \mathrm{mec} .14838$

Doheny-Adams, T., Hunt, L., Franks, P. J., Beerling, D. J., and Gray, J. E. (2012). Genetic manipulation of stomatal density influences stomatal size, plant growth and tolerance to restricted water supply across a growth carbon dioxide gradient. Philos. Trans. R. Soc. Lond. Ser. B Biol. Sci. 367, 547-555. doi: $10.1098 /$ rstb.2011.0272

Dow, G. J., and Bergmann, D. C. (2014). Patterning and processes: how stomatal development defines physiological potential. Curr. Opin. Plant Biol. 21, 67-74. doi: 10.1016/j.pbi.2014.06.007

Dow, G. J., Bergmann, D. C., and Berry, J. A. (2014a). An integrated model of stomatal development and leaf physiology. New Phytol. 201, 1218-1226. doi: $10.1111 / \mathrm{nph} .12608$

Dow, G. J., Berry, J. A., and Bergmann, D. C. (2014b). The physiological importance of developmental mechanisms that enforce proper stomatal spacing in Arabidopsis thaliana. New Phytol. 201, 1205-1217. doi: 10.1111/ nph.12586

Drake, P. L., Froend, R. H., and Franks, P. J. (2013). Smaller, faster stomata: scaling of stomatal size, rate of response, and stomatal conductance. J. Exp. Bot. 64, 495-505. doi: 10.1093/jxb/ers347

Elliott-Kingston, C., Haworth, M., Yearsley, J. M., Batke, S. P., Lawson, T., and McElwain, J. C. (2016). Does size matter? Atmospheric $\mathrm{CO}_{2}$ may be a stronger driver of stomatal closing rate than stomatal size in taxa that diversified under low $\mathrm{CO}_{2}$. Front. Plant Sci. 7:1253. doi: 10.3389/ fpls.2016.01253

Fanourakis, D., Giday, H., Milla, R., Pieruschka, R., Kjaer, K. H., Bolger, M., et al. (2015). Pore size regulates operating stomatal conductance, while stomatal densities drive the partitioning of conductance between leaf sides. Ann. Bot. 115, 555-565. doi: 10.1093/aob/mcu247

Farquhar, G. D., and Sharkey, T. D. (1982). Stomatal conductance and photosynthesis. Annu. Rev. Plant Physiol. 33, 317-345. doi: 10.1146/annurev. pp.33.060182.001533

Field, K. J., Duckett, J. G., Cameron, D. D., and Pressel, S. (2015). Stomatal density and aperture in non-vascular land plants are non-responsive to above-ambient atmospheric $\mathrm{CO}_{2}$ concentrations. Ann. Bot. 115, 915-922. doi: $10.1093 / \mathrm{aob} / \mathrm{mcv} 021$

Flexas, J. (2016). Genetic improvement of leaf photosynthesis and intrinsic water use efficiency in C3 plants: why so much little success? Plant Sci. 251, 155-161. doi: 10.1016/J.PLANTSCI.2016.05.002

Flexas, J., and Medrano, H. (2002). Drought-inhibition of photosynthesis in C3 plants: stomatal and non-stomatal limitations revisited. Ann. Bot. 89, 183-189. doi: $10.1093 / \mathrm{aob} / \mathrm{mcf027}$

Flexas, J., Niinemets, Ü., Gallé, A., Barbour, M. M., Centritto, M., Diaz-Espejo, A., et al. (2013). Diffusional conductances to $\mathrm{CO}_{2}$ as a target for increasing photosynthesis and photosynthetic water-use efficiency. Photosynth. Res. 117, 45-59. doi: 10.1007/s11120-013-9844-Z

Franks, P. J., and Beerling, D. J. (2009). Maximum leaf conductance driven by $\mathrm{CO}_{2}$ effects on stomatal size and density over geologic time. Proc. Natl. Acad. Sci. U. S. A. 106, 10343-10347. doi: 10.1073/pnas.0904209106

Franks, P. J., Drake, P. L., and Beerling, D. J. (2009). Plasticity in maximum stomatal conductance constrained by negative correlation between stomatal 
size and density: an analysis using Eucalyptus globulus. Plant Cell Environ. 32, 1737-1748. doi: 10.1111/j.1365-3040.2009.002031.x

Franks, P. J., and Farquhar, G. D. (2001). The effect of exogenous abscisic acid on stomatal development, stomatal mechanics, and leaf gas exchange in Tradescantia virginiana. Available at: www.plantphysiol.org (Accessed July 31, 2018).

Franks, P. J., and Farquhar, G. D. (2007). The mechanical diversity of stomata and its significance in gas exchange control. Plant Physiol. 143, 78-97. doi: 10.1104/pp.106.089367

Franks, P. J., Leitch, I. J., Ruszala, E. M., Hetherington, A. M., and Beerling, D. J. (2012). Physiological framework for adaptation of stomata to $\mathrm{CO}_{2}$ from glacial to future concentrations. Philos. Trans. R. Soc. Lond. Ser. B Biol. Sci. 367, 537-546. doi: 10.1098/rstb.2011.0270

Franks, P. J., Doheny-Adams, W. T., Britton-Harper, Z. J., and Gray, J. E. (2015). Increasing water-use efficiency directly through genetic manipulation of stomatal density. New Phytol. 207, 188-195. doi: 10.1111/nph.13347

Galdon-Armero, J., Fullana-Pericas, M., Mulet, P. A., Conesa, M. A., Martin, C., and Galmes, J. (2018). The ratio of trichomes to stomata is associated with water use efficiency in tomato. Plant J. doi: 10.1111/tpj.14055

Gao, X., Zou, C., Wang, L., and Zhang, F. (2006). Silicon decreases transpiration rate and conductance from stomata of maize plants. J. Plant Nutr. 29, 1637-1647. doi: 10.1080/01904160600851494

Gay, A. P., and Hurd, R. G. (1975). The influence of light on stomatal density in the tomato. New Phytol. 75, 37-46. doi: 10.1111/j.1469-8137.1975.tb01368.x

Głowacka, K., Kromdijk, J., Kucera, K., Xie, J., Cavanagh, A. P., Leonelli, L., et al. (2018). Photosystem II subunit S overexpression increases the efficiency of water use in a field-grown crop. Nat. Commun. 9:868. doi: 10.1038/ s41467-018-03231-x

Goodstein, D. M., Shu, S., Howson, R., Neupane, R., Hayes, R. D., Fazo, J., et al. (2012). Phytozome: a comparative platform for green plant genomics. Nucleic Acids Res. 40, D1178-D1186. doi: 10.1093/nar/gkr944

Grantz, D. A., and Zeiger, E. (1986). Stomatal responses to light and leaf-air water vapor pressure difference show similar kinetics in sugarcane and soybean. Plant Physiol. 81, 865-868. doi: 10.1104/pp.81.3.865

Guo, J., Xu, W., Yu, X., Shen, H., Li, H., Cheng, D., et al. (2016). Cuticular wax accumulation is associated with drought tolerance in wheat near-isogenic lines. Front. Plant Sci. 7:1809. doi: 10.3389/fpls.2016.01809

Hara, K., Kajita, R., Torii, K. U., Bergmann, D. C., and Kakimoto, T. (2007). The secretory peptide gene EPF1 enforces the stomatal one-cell-spacing rule. Genes Dev. 21, 1720-1725. doi: 10.1101/gad.1550707

Haworth, M., Elliott-Kingston, C., and McElwain, J. C. (2013). Co-ordination of physiological and morphological responses of stomata to elevated $\left[\mathrm{CO}_{2}\right]$ in vascular plants. Oecologia 171, 71-82. doi: 10.1007/s00442-012-2406-9

Haworth, M., Killi, D., Materassi, A., Raschi, A., and Centritto, M. (2016). Impaired stomatal control is associated with reduced photosynthetic physiology in crop species grown at elevated $\left[\mathrm{CO}_{2}\right]$. Front. Plant Sci. 7:1568. doi: 10.3389/ fpls.2016.01568

Haworth, M., Scutt, C. P., Douthe, C., Marino, G., Gomes, M. T. G., Loreto, F, et al. (2018). Allocation of the epidermis to stomata relates to stomatal physiological control: stomatal factors involved in the evolutionary diversification of the angiosperms and development of amphistomaty. Environ. Exp. Bot. 151, 55-63. doi: 10.1016/j.envexpbot.2018.04.010

Hepworth, C., Caine, R. S., Harrison, E. L., Sloan, J., and Gray, J. E. (2018). Stomatal development: focusing on the grasses. Curr. Opin. Plant Biol. 41, 1-7. doi: 10.1016/J.PBI.2017.07.009

Hepworth, C., Doheny-Adams, T., Hunt, L., Cameron, D. D., and Gray, J. E. (2015). Manipulating stomatal density enhances drought tolerance without deleterious effect on nutrient uptake. New Phytol. 208, 336-341. doi: 10.1111/nph.13598

Hepworth, C., Turner, C., Landim, M. G., Cameron, D., and Gray, J. E. (2016). Balancing water uptake and loss through the coordinated regulation of stomatal and root development. PLoS One 11:e0156930. doi: 10.1371/journal. pone. 0156930

Hetherington, A. M., and Woodward, F. I. (2003). The role of stomata in sensing and driving environmental change. Nature 424, 901-908. doi: 10.1038/ nature 01843

Howden, S. M., Soussana, J. -F., Tubiello, F. N., Chhetri, N., Dunlop, M., and Meinke, H. (2007). Adapting agriculture to climate change. Proc. Natl. Acad. Sci. U. S. A. 104, 19691-19696. doi: 10.1073/pnas.0701890104

Hughes, J., Hepworth, C., Dutton, C., Dunn, J. A., Hunt, L., Stephens, J., et al. (2017). Reducing stomatal density in barley improves drought tolerance without impacting on yield. Plant Physiol. 174, 776-787. doi: 10.1104/ pp.16.01844

Hunt, L., Amsbury, S., Baillie, A., Movahedi, M., Mitchell, A., Afsharinafar, M., et al. (2017). Formation of the stomatal outer cuticular ledge requires a guard cell wall proline-rich protein. Plant Physiol. 174, 689-699. doi: 10.1104/pp.16.01715

Hunt, L., Bailey, K. J., and Gray, J. E. (2010). The signalling peptide EPFL9 is a positive regulator of stomatal development. New Phytol. 186, 609-614. doi: $10.1111 / \mathrm{j} .1469-8137.2010 .03200 . \mathrm{x}$

Hunt, L., and Gray, J. E. (2009). The signaling peptide EPF2 controls asymmetric cell divisions during stomatal development. Curr. Biol. 19, 864-869. doi: 10.1016/J.CUB.2009.03.069

Ichie, T., Inoue, Y., Takahashi, N., Kamiya, K., and Kenzo, T. (2016). Ecological distribution of leaf stomata and trichomes among tree species in a Malaysian lowland tropical rain forest. J. Plant Res. 129, 625-635. doi: 10.1007/ s10265-016-0795-2

Iglesias, A., and Garrote, L. (2015). Adaptation strategies for agricultural water management under climate change in Europe. Agric. Water Manag. 155, 113-124. doi: 10.1016/J.AGWAT.2015.03.014

IPCC. (2014). Climate change 2014 synthesis report summary chapter for policymakers. IPCC 31.

Jordan, G. J., Carpenter, R. J., Koutoulis, A., Price, A., and Brodribb, T. J. (2015). Environmental adaptation in stomatal size independent of the effects of genome size. New Phytol. 205, 608-617. doi: 10.1111/nph.13076

Kardiman, R., and Raebild, A. (2017). Relationship between stomatal density, size and speed of opening in Sumatran rainforest species. Tree Physiol. 38, 696-705. doi: 10.1093/treephys/tpx149

Kollist, H., Nuhkat, M., and Roelfsema, M. R. G. (2014). Closing gaps: linking elements that control stomatal movement. New Phytol. 203, 44-62. doi: 10.1111/nph.12832

Kromdijk, J., Głowacka, K., Leonelli, L., Gabilly, S. T., Iwai, M., Niyogi, K. K., et al. (2016). Improving photosynthesis and crop productivity by accelerating recovery from photoprotection. Science 354, 857-861. doi: 10.1126/science. aai8878

Lake, J. A., Quick, W. P., Beerling, D. J., and Woodward, F. I. (2001). Plant development: signals from mature to new leaves. Nature 411:154. doi $10.1038 / 35075660$

Lawson, T., and Blatt, M. R. (2014). Stomatal size, speed, and responsiveness impact on photosynthesis and water use efficiency. Plant Physiol. 164, 1556-1570. doi: 10.1104/pp.114.237107

Lawson, T., and Vialet-Chabrand, S. (2019). Speedy stomata, photosynthesis and plant water use efficiency. New Phytol. 221, 93-98. doi: 10.1111/nph.15330

Lee, J. S., Hnilova, M., Maes, M., Lin, Y. -C. L., Putarjunan, A., Han, S. -K. et al. (2015). Competitive binding of antagonistic peptides fine-tunes stomatal patterning. Nature 522, 439-443. doi: 10.1038/nature14561

Lefebvre, S., Lawson, T., Zakhleniuk, O. V., Lloyd, J. C., Raines, C. A., and Fryer, M. (2005). Increased sedoheptulose-1,7-bisphosphatase activity in transgenic tobacco plants stimulates photosynthesis and growth from an early stage in development. Plant Physiol. 138, 451-460. doi: 10.1104/pp.104.055046

Liao, J. -X., Chang, J., and Wang, G. -X. (2005). Stomatal density and gas exchange in six wheat cultivars. Cereal Res. Commun. 33, 719-726. doi: 10.1556/CRC.33.2005.2-3.140

Lipper, L., Thornton, P., Campbell, B. M., Baedeker, T., Braimoh, A., Bwalya, M., et al. (2014). Climate-smart agriculture for food security. Nat. Clim. Chang. 4, 1068-1072. doi: 10.1038/nclimate2437

Liu, T., Ohashi-Ito, K., and Bergmann, D. C. (2009). Orthologs of Arabidopsis thaliana stomatal bHLH genes and regulation of stomatal development in grasses. Development 136, 2265-2276. doi: 10.1242/dev.032938. Available at: http://dev. biologists.org/content/136/13/2265.long (Accessed June 4, 2017).

Liu, Y., Qin, L., Han, L., Xiang, Y., and Zhao, D. (2015). Overexpression of maize SDD1 (ZmSDD1) improves drought resistance in Zea mays L. by reducing stomatal density. Plant Cell Tissue Organ Cult. 122, 147-159. doi: 10.1007/s11240-015-0757-8

Lobell, D. B., Schlenker, W., and Costa-Roberts, J. (2011). Climate trends and global crop production since 1980. Science 333, 616-620. doi: 10.1126/ science. 1204531

Lu, Z. -M. (1989). Ratio of stomatal resistance on two sides of wheat leaves as affected by soil water content. Agric. For. Meteorol. 49, 1-7. doi: 10.1016/0168-1923(89)90057-9 
Lu, Z., Quiñones, M. A., and Zeiger, E. (1993). Abaxial and adaxial stomata from Pima cotton (Gossypium barbadense L.) differ in their pigment content and sensitivity to light quality. Plant Cell Environ. 16, 851-858. doi: 10.1111/ j.1365-3040.1993.tb00507.x

MacAlister, C. A., Ohashi-Ito, K., and Bergmann, D. C. (2007). Transcription factor control of asymmetric cell divisions that establish the stomatal lineage. Nature 445, 537-540. doi: 10.1038/nature05491

McAdam, S. A. M., Sussmilch, F. C., and Brodribb, T. J. (2016). Stomatal responses to vapour pressure deficit are regulated by high speed gene expression in angiosperms. Plant Cell Environ. 39, 485-491. doi: 10.1111/ pce. 12633

McAusland, L., Vialet-Chabrand, S., Davey, P., Baker, N. R., Brendel, O., and Lawson, T. (2016). Effects of kinetics of light-induced stomatal responses on photosynthesis and water-use efficiency. New Phytol. 211, 1209-1220. doi: $10.1111 /$ nph. 14000

McElwain, J. C., Yiotis, C., and Lawson, T. (2016). Using modern plant trait relationships between observed and theoretical maximum stomatal conductance and vein density to examine patterns of plant macroevolution. New Phytol. 209, 94-103. doi: 10.1111/nph.13579

McKown, K. H., and Bergmann, D. C. (2018). Grass stomata. Curr. Biol. 28, R814-R816. doi: 10.1016/j.cub.2018.05.074

Medrano, H., Tomás, M., Martorell, S., Flexas, J., Hernández, E., Rosselló, J., et al. (2015). From leaf to whole-plant water use efficiency (WUE) in complex canopies: limitations of leaf WUE as a selection target. Crop J. 3, 220-228. doi: 10.1016/J.CJ.2015.04.002

Merilo, E., Jõesaar, I., Brosché, M., and Kollist, H. (2014). To open or to close: species-specific stomatal responses to simultaneously applied opposing environmental factors. New Phytol. 202, 499-508. doi: 10.1111/nph.12667

Miyazawa, S. -I., Livingston, N. J., and Turpin, D. H. (2006). Stomatal development in new leaves is related to the stomatal conductance of mature leaves in poplar (Populus trichocarpa $\times$ P. deltoides). J. Exp. Bot. 57, 373-380. doi: $10.1093 / \mathrm{jxb} / \mathrm{eri} 278$

Monda, K., Araki, H., Kuhara, S., Ishigaki, G., Akashi, R., Negi, J., et al. (2016). Enhanced stomatal conductance by a spontaneous Arabidopsis tetraploid, Me-0, results from increased stomatal size and greater stomatal aperture. Plant Physiol. 170, 1435-1444. doi: 10.1104/pp.15.01450

Morales-Navarro, S., Pérez-Díaz, R., Ortega, A., de Marcos, A., Mena, M., Fenoll, C., et al. (2018). Overexpression of a SDD1-like gene from wild tomato decreases stomatal density and enhances dehydration avoidance in Arabidopsis and cultivated tomato. Front. Plant Sci. 9:940. doi: 10.3389/ fpls.2018.00940

Mott, K. A. (2009). Opinion: stomatal responses to light and $\mathrm{CO}_{2}$ depend on the mesophyll. Plant Cell Environ. 32, 1479-1486. doi: 10.1111/j.1365-3040.2009.02022.x

Müller, H. M., Schäfer, N., Bauer, H., Geiger, D., Lautner, S., Fromm, J., et al. (2017). The desert plant Phoenix dactylifera closes stomata via nitrateregulated SLAC1 anion channel. New Phytol. 216, 150-162. doi: 10.1111/ nph. 14672

Mustilli, A. -C. (2002). Arabidopsis OST1 protein kinase mediates the regulation of stomatal aperture by abscisic acid and acts upstream of reactive oxygen species production. Plant Cell (online) 14, 3089-3099. doi: 10.1105/tpc.007906

Ohsumi, A., Kanemura, T., Homma, K., Horie, T., and Shiraiwa, T. (2007). Genotypic variation of stomatal conductance in relation to stomatal density and length in rice (Oryza sativa L.). Plant Prod. Sci. 10, 322-328. doi: 10.1626/pps.10.322

Ort, D. R., Merchant, S. S., Alric, J., Barkan, A., Blankenship, R. E., Bock, R., et al. (2015). Redesigning photosynthesis to sustainably meet global food and bioenergy demand. Proc. Natl. Acad. Sci. 112, 8529-8536. doi: 10.1073/ pnas. 1424031112

Ouyang, W., Struik, P. C., Yin, X., and Yang, J. (2017). Stomatal conductance, mesophyll conductance, and trans piration efficiency in relation to leaf anatomy in rice and wheat genotypes under drought. J. Exp. Bot. 68, 5191-5205. doi: 10.1093/jxb/erx314

Pillitteri, L. J., and Dong, J. (2013). Stomatal development in Arabidopsis. Arab. B. 11:e162. doi: 10.1199/tab.0162

Pillitteri, L. J., and Torii, K. U. (2012). Mechanisms of stomatal development. Annu. Rev. Plant Biol. 63, 591-614. doi: 10.1146/annurev-arplant-042811-105451

Qi, X., and Torii, K. U. (2018). Hormonal and environmental signals guiding stomatal development. BMC Biol. 16:21. doi: 10.1186/s12915-018-0488-5

Raissig, M. T., Abrash, E., Bettadapur, A., Vogel, J. P., and Bergmann, D. C. (2016). Grasses use an alternatively wired bHLH transcription factor network to establish stomatal identity. Proc. Natl. Acad. Sci. 113, 8326-8331. doi: $10.1073 /$ pnas. 1606728113

Raissig, M. T., Matos, J. L., Gil, M. X. A., Kornfeld, A., Bettadapur, A., Abrash, E., et al. (2017). Mobile MUTE specifies subsidiary cells to build physiologically improved grass stomata. Science 355, 1215-1218. doi: 10.1126/ science.aal3254

Raschke, K., and Fellows, M. P. (1971). Stomatal movement in Zea mays: shuttle of potassium and chloride between guard cells and subsidiary cells. Planta 101, 296-316. doi: 10.1007/BF00398116

Rudall, P. J., Chen, E. D., and Cullen, E. (2017). Evolution and development of monocot stomata. Am. J. Bot. 104, 1122-1141. doi: 10.3732/ajb.1700086

Rudall, P. J., Hilton, J., and Bateman, R. M. (2013). Several developmental and morphogenetic factors govern the evolution of stomatal patterning in land plants. New Phytol. 200, 598-614. doi: 10.1111/nph.12406

Sack, F. D. (1994). Structure of the stomatal complex of the monocot Flagellaria indica. Am. J. Bot. 81, 339-344. doi: 10.2307/2445461

Sack, L., and Buckley, T. N. (2016). The developmental basis of stomatal density and flux. Plant Physiol. 171, 2358-2363. doi: 10.1104/pp.16.00476

Schäfer, N., Maierhofer, T., Herrmann, J., Jørgensen, M. E., Lind, C., von Meyer, K., et al. (2018). A tandem amino acid residue motif in guard cell SLAC1 anion channel of grasses allows for the control of stomatal aperture by nitrate. Curr. Biol. 28, 1370-1379.e5. doi: 10.1016/J.CUB.2018.03.027

Schroeder, J. I., Allen, G. J., Hugouvieux, V., Kwak, J. M., and Waner, D. (2001). Guard cell signal transduction. Annu. Rev. Plant Physiol. Plant Mol. Biol. 52, 627-658. doi: 10.1146/annurev.arplant.52.1.627

Schuler, M. L., Sedelnikova, O. V., Walker, B. J., Westhoff, P., and Langdale, J. A. (2018). SHORTROOT-mediated increase in stomatal density has no impact on photosynthetic efficiency. Plant Physiol. 176, 757-772. doi: 10.1104/ pp.17.01005

Sekiya, N., and Yano, K. (2008). Stomatal density of cowpea correlates with carbon isotope discrimination in different phosphorus, water and $\mathrm{CO}_{2}$ environments. New Phytol. 179, 799-807. doi: 10.1111/j.1469-8137.2008.02518.x

Sherwood, S., and Fu, Q. (2014). Climate change. A drier future? Science 343, 737-739. doi: 10.1126/science. 1247620

Sorrentino, G., Haworth, M., Wahbi, S., Mahmood, T., Zuomin, S., and Centritto, M. (2016). Abscisic acid induces rapid reductions in mesophyll conductance to carbon dioxide. PLoS One 11:e0148554. doi: 10.1371/journal.pone.0148554

Stebbins, G. L., and Shah, S. S. (1960). Developmental studies of cell differentiation in the epidermis of monocotyledons. Dev. Biol. 2, 477-500. doi: 10.1016/0012-1606(60)90050-6

Sugano, S. S., Shimada, T., Imai, Y., Okawa, K., Tamai, A., Mori, M., et al. (2010). Stomagen positively regulates stomatal density in Arabidopsis. Nature 463, 241-244. doi: 10.1038/nature08682

Sun, Y., Yan, F., Cui, X., and Liu, F. (2014). Plasticity in stomatal size and density of potato leaves under different irrigation and phosphorus regimes. J. Plant Physiol. 171, 1248-1255. doi: 10.1016/J.JPLPH.2014.06.002

Sutimantanapi, D., Pater, D., and Smith, L. G. (2014). Divergent roles for maize PAN1 and PAN2 receptor-like proteins in cytokinesis and cell morphogenesis. Plant Physiol. 164, 1905-1917. doi: 10.1104/pp.113.232660

Taylor, S. H., Franks, P. J., Hulme, S. P., Spriggs, E., Christin, P. A., Edwards, E. J., et al. (2012). Photosynthetic pathway and ecological adaptation explain stomatal trait diversity amongst grasses. New Phytol. 193, 387-396. doi: 10.1111/j.1469-8137.2011.03935.x

Taylor, S. H., Ripley, B. S., Woodward, F. I., and Osborne, C. P. (2011). Drought limitation of photosynthesis differs between C3 and C4 grass species in a comparative experiment. Plant Cell Environ. 34, 65-75. doi: 10.1111/j.1365-3040.2010.02226.x

Teare, I. D., Peterson, C. J., and Law, A. G. (1971). Size and frequency of leaf stomata in cultivars of Triticum aestivum and other triticum species 1. Crop Sci. 11, 496. doi: 10.2135/cropsci1971.0011183X001100040010x

Tombesi, S., Nardini, A., Frioni, T., Soccolini, M., Zadra, C., Farinelli, D., et al. (2015). Stomatal closure is induced by hydraulic signals and maintained by ABA in drought-stressed grapevine. Sci. Rep. 5, 12449. doi: 10.1038/ srep 12449

Varshney, R. K., Singh, V. K., Kumar, A., Powell, W., and Sorrells, M. E. (2018). Can genomics deliver climate-change ready crops? Curr. Opin. Plant Biol. 45, 205-211. doi: 10.1016/J.PBI.2018.03.007

Vatén, A., and Bergmann, D. C. (2012). Mechanisms of stomatal development: an evolutionary view. EvoDevo 3, 11. doi: 10.1186/2041-9139-3-11 
Vico, G., Manzoni, S., Palmroth, S., and Katul, G. (2011). Effects of stomatal delays on the economics of leaf gas exchange under intermittent light regimes. New Phytol. 192, 640-652. doi: 10.1111/j.1469-8137.2011.03847.x

Von Groll, U., Berger, D., and Altmann, T. (2002). The subtilisin-like serine protease SDD1 mediates cell-to-cell signaling during Arabidopsis stomatal development. Plant Cell 14, 1527-1539. doi: 10.1105/tpc.001016

Wang, C., Liu, S., Dong, Y., Zhao, Y., Geng, A., Xia, X., et al. (2016). PdEPF1 regulates water-use efficiency and drought tolerance by modulating stomatal density in poplar. Plant Biotechnol. J. 14, 849-860. doi: 10.1111/pbi.12434

Willmer, C. M., and Fricker, M. D. (1996). Stomata. 2nd edition. London: Chapman \& Hall. Available at: https://books.google.co.uk/books/about/Stomata. html?id=AXvwAAAAMAAJ\&redir_esc=y (Accessed November 19, 2018).

Winter, D., Vinegar, B., Nahal, H., Ammar, R., Wilson, G. V., and Provart, N. J. (2007). An "electronic fluorescent pictograph" browser for exploring and analyzing large-scale biological data sets. PLoS One 2:e718. doi: 10.1371/ journal.pone.0000718

Wong, S. C., Cowan, I. R., and Farquhar, G. D. (1979). Stomatal conductance correlates with photosynthetic capacity. Nature 282, 424-426. doi: $10.1038 / 282424 \mathrm{a} 0$

Woodward, F. I. (1987). Stomatal numbers are sensitive to increases in $\mathrm{CO}_{2}$ from pre-industrial levels. Nature 327, 617-618. doi: 10.1038/327617a0

$\mathrm{Xu}, \mathrm{Z}$., and Zhou, G. (2008). Responses of leaf stomatal density to water status and its relationship with photosynthesis in a grass. J. Exp. Bot. 59, 3317-3325. doi: 10.1093/jxb/ern185

Yan, F., Sun, Y., Song, F., and Liu, F. (2012). Differential responses of stomatal morphology to partial root-zone drying and deficit irrigation in potato leaves under varied nitrogen rates. Sci. Hortic. 145, 76-83. doi: 10.1016/J. SCIENTA.2012.07.026

Yin, X., Biswal, A. K., Dionora, J., Perdigon, K. M., Balahadia, C. P., Mazumdar, S., et al. (2017). CRISPR-Cas9 and CRISPR-Cpf1 mediated targeting of a stomatal developmental gene EPFL9 in rice. Plant Cell Rep. 36, 745-757. doi: 10.1007/s00299-017-2118-Z

Yoo, C. Y., Pence, H. E., Jin, J. B., Miura, K., Gosney, M. J., Hasegawa, P. M., et al. (2010). The Arabidopsis GTL1 transcription factor regulates water use efficiency and drought tolerance by modulating stomatal density via transrepression of SDD1. Plant Cell 22, 4128-4141. doi: 10.1105/tpc.110.078691
Yu, L., Chen, X., Wang, Z., Wang, S., Wang, Y., Zhu, Q., et al. (2013). Arabidopsis enhanced drought tolerance1/HOMEODOMAIN GLABROUS11 confers drought tolerance in transgenic rice without yield penalty. Plant Physiol. 162, 1378-1391. doi: 10.1104/pp.113.217596

Zeiger, E., Farquhar, G. D., and Cowan, I. R. (1987). Stomatal function. Stanford, California: Stanford University Press.

Zeisler-Diehl, V., Müller, Y., and Schreiber, L. (2018). Epicuticular wax on leaf cuticles does not establish the transpiration barrier, which is essentially formed by intracuticular wax. J. Plant Physiol. 227, 66-74. doi: 10.1016/j. jplph.2018.03.018

Zhang, X., Facette, M., Humphries, J. A., Shen, Z., Park, Y., Sutimantanapi, D., et al. (2012). Identification of PAN2 by quantitative proteomics as a leucine-rich repeat-receptor-like kinase acting upstream of PAN1 to polarize cell division in maize. Plant Cell 24, 4577-4589. doi: 10.1105/ tpc.112.104125

Zhao, W., Sun, Y., Kjelgren, R., and Liu, X. (2015). Response of stomatal density and bound gas exchange in leaves of maize to soil water deficit. Acta Physiol. Plant. 37, 1704. doi: 10.1007/s11738-014-1704-8

Zhou, Y., Lam, H. M., and Zhang, J. (2007). Inhibition of photosynthesis and energy dissipation induced by water and high light stresses in rice. J. Exp. Bot. 58, 1207-1217. doi: 10.1093/jxb/erl291

Zoulias, N., Harrison, E. L., Casson, S. A., and Gray, J. E. (2018). Molecular control of stomatal development. Biochem. J. 475, 441-454. doi: 10.1042/ BCJ20170413

Conflict of Interest Statement: The authors declare that the research was conducted in the absence of any commercial or financial relationships that could be construed as a potential conflict of interest.

Copyright (c) 2019 Bertolino, Caine and Gray. This is an open-access article distributed under the terms of the Creative Commons Attribution License (CC $B Y)$. The use, distribution or reproduction in other forums is permitted, provided the original author(s) and the copyright owner(s) are credited and that the original publication in this journal is cited, in accordance with accepted academic practice. No use, distribution or reproduction is permitted which does not comply with these terms. 